\title{
Religious Violence in Late Antiquity
}

\author{
PETER VAN NUFFELEN
}

\section{Late Antiquity and Modernity}

This chapter is the first in this book to have 'religious violence' in its title. Late antiquity, then, seems to mark the introduction of a new type of violence. Such is the conclusion of a leading scholar of late antique violence, Johannes Hahn, who writes: 'Religious violence as a phenomenon of public life is indeed peculiar to Late Antiquity'. Hahn attributes this development to the conversion of Constantine and the Roman Empire

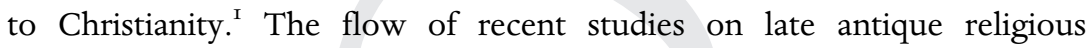
violence and its virtual absence in studies of the classical world seem to confirm that judgement.

Yet, is religious violence really a typically late antique and Christian feature? If that were the case, what are we to do with the anti-Christian measures of the Roman state, for example those of Diocletian? What about the anti-Manichaean decrees of this emperor? What about the desecration of the Jewish temple in I68 в се by the Seleucid King Antiochus IV, and the suppression of the Bacchanalia by the Roman Senate in I86 BCE? The list could be many times longer. Maybe there are, after all, more chapters to be written on religious violence in ancient Greece and Rome.

The seemingly obvious nature of the identification of religious violence and late antiquity is reflected in a general lack of definition of what counts as such. Scholars of late antique violence rarely deal with sacralised violence in cult, like sacrifice, which is generally seen to have been marginalised. Blood sacrifice had been abandoned by the three monotheistic religions of late

I Johannes Hahn, 'The Challenge of Religious Violence: Imperial Ideology and Policy in the Fourth Century', in J. Wienand (ed.), Contested Monarchy: Integrating the Roman Empire in the Fourth Century AD (New York: Oxford University Press, 2015), pp. 379-404, at p. 379. 
antiquity and within paganism it is thought to have been decisively weakened. If the death of Christ lies at the heart of Christian worship, it was considered to have been a final act and was commemorated in a bloodless fashion, as Christian apologists were proud to point out. Scholars do not focus on violence tied to religious occasions and festivals. Religious ceremonies could be flashpoints of conflict, but it is hard to discern cyclical, ritual patterns such as those observed for the Middle Ages by David Nirenberg, who linked violence to particular periods of the liturgical year. ${ }^{2}$ Usually, religious violence is understood as violent actions against religious groups and their members by another religious group. The archetypical events of this type are the destruction of temples and synagogues, and attacks on pagans. These are exemplified in a number of well-known cases, such as the destruction of the Serapeion in Alexandria (39I CE), the attack on the synagogue in Callinicum in Syria $(388 \mathrm{CE}$ ), and the murder of the philosopher Hypatia (c. $4 \mathrm{I} 5 \mathrm{CE}$ ). The focus, then, is on social conflict between religious groups. The net is sometimes cast wider, situating such violence in the context of imperial measures against non-Christian and heretical groups and set against the background of a narrative that emphasises the violent imposition of Christian orthodoxy on the Roman Empire through the twin efforts of church and state. This narrative has, in fact, deep roots in the intellectual history of the West.

If it is questionable that religious violence is typically late antique, the identification is sustained by the attribution of an intrinsically violent nature to monotheistic religions. These are supposed, theologically, to make a strong distinction between truth and falsity, and thus, in sociological terms, to have a strong in/out dimension. ${ }^{3}$ The transition from a polytheistic to a monotheistic society must then be inherently violent. Philosophically problematic, such an understanding of religion is historically implausible, as one can find many periods of tolerance in monotheistic religions and of intolerance by polytheistic religions. For late antiquity, this point has been repeatedly made by Harold Drake, who shows that the identification of monotheism with violence and intolerance is an Enlightenment trope that does not suit the evidence. The flipside of this particular trope is the idea that Greek and Roman

2 David Nirenberg, Communities of Violence: Persecution of Minorities in the Middle Ages (Princeton, NJ: Princeton University Press, 1996).

3 The idea is now usually associated with Jan Assmann, The Price of Monotheism (Stanford, CA: Stanford University Press, 20Io). 
polytheism was essentially tolerant and non-violent, a view that, as we have seen, is open to question. ${ }^{4}$

Drake rightly points to the historical genesis of the association between monotheism and violence, but the roots of the identification of late antiquity and religious violence go deeper. It started during the Reformation, when Protestants attacked the Catholic Church for having degenerated. In order to do so, they had to construct a historical narrative that identified the moment when the church had lapsed. A widely accepted point in time was the conversion of Constantine, who struck the alliance between state and church. This led to a twofold corruption. On the one hand, one could argue that the church, which previously had had no coercive powers, could now use violence against heretics, pagans and Jews, and started to lobby the state to abandon its previously tolerant attitude towards followers of other religions. On the other, one could blame the state and argue that it started to use the church for its own purposes and turned it into an instrument of oppression. The 'Constantinian turn' thus became the moment when violence entered the church. Indeed, the idea of a fundamental contrast between pre-Nicene and post-Nicene Christianity is still deeply rooted in scholarship and popular perception. $^{5}$

The narrative is further sustained by our modern perception of the role of the state and its relationship to religion. Two salient features of the modern state are relevant in this respect. First, the modern, Western state arrogates itself a monopoly of violence, seen as the guarantee of a peaceful and stable society. Only the state can legitimately use violence and it therefore seeks to limit the use of coercion by other institutions. Second, religious toleration lies at the heart of the modern state and is seen as a quality that was hard-won against religion and the Catholic Church in particular. Through the emphasis on the state as the primary source of identity, religion appears as particularistic and potentially disruptive of a society built around a core of shared values. From a modern perspective, then, late antiquity cannot but appear as the mirror image of our (ideal) self: a state seemingly abandons its monopoly of violence to a church that brings social disruption. This is reflected in the

4 Most recently Harold A. Drake, 'Intolerance, Religious Violence and Political Legitimacy in Late Antiquity', Journal of the American Academy of Religion 79.I (2011), 193-235. For a genealogy of the trope of classical toleration, see Joachim Losehand, "'The Religious Harmony in the Ancient World": Vom Mythos religiöser Toleranz in der Antike', Göttinger Forum für Altertumswissenschaften I2 (2009), 99-I32.

5 D. H. Williams, 'Constantine, Nicea, and the "Fall of the Church", in L. Ayres and G. Jones (eds.), Christian Origins: Theology, Rhetoric and Community (London: Routledge, I998), pp. II7-36. 
Religious Violence in Late Antiquity

tone of explicit condemnation in which much scholarship on the topic is couched. ${ }^{6}$

\section{Towards the Dissolution of Religious Violence in Late Antiquity}

The traditional narrative traces an ascendant line of religious violence in late antiquity. The support given to Christianity by Constantine leads to other religions being progressively driven out of society. The process is reflected in an increasingly strict legislation, culminating in the outlawing of pagan acts by Theodosius I (39I-2 CE) and accompanied by extrajudicial attacks by Christian groups on cult places. The fractious nature of Christianity, in turn, entails deep conflict between different groups claiming orthodoxy, resulting in numerous clashes, which are exploited by bishops to establish their own authority. The process reaches a climax in the reign of Justinian (527-65 CE), whose legislation seeks to eliminate all dissent. With its double emphasis on legislation and violence, this narrative sees the identification of church and state as a legacy of late antiquity - a knot that only modernity would disentangle.

The sources provide, at first glance, much confirmation of this narrative. One regularly encounters stories of violent destructions and clashes, seemingly backing up the idea of widespread religious violence. Yet, scholars recently have grown sensitive to the limits of the evidence. First, the limited number of instances of religious violence are highlighted. For example, ancient accounts of destructions of temples, such as that of the Serapeion in Alexandria (39I CE), of Marnas in Gaza as reported in the life of Porphyry (possibly early fifth century), or the ones alleged by Libanius in his oration For the Temples (38I-92 CE), are not very numerous. Moreover, the archaeological evidence does not bear out a picture of widespread destruction of places of worship. This does not mean that no destruction took place, but the act may be rarer than Libanius' highly evocative image of monks descending as locusts on the Syrian countryside to destroy temples might suggest. ${ }^{7}$ Wolfram Kinzig has made a similar argument for anti-Jewish violence. He

6 The following titles are eloquent: Eberhard Sauer, The Archaeology of Religious Hatred in the Roman and Early Medieval World (Stroud: Tempus, 2003); Polymnia Athanassiadi, Vers la pensée unique: La montée de l'intolérance dans l'Antiquité Tardive (Paris: Belles Lettres, 20IO).

7 Lib. 30.8. Cf. Luke Lavan's introduction to L. Lavan and M. Mulryan (eds.), The Archaeology of Late Antique Paganism (Leiden: Brill, 20II), pp. xv-lxv. 
counts twenty violent episodes from the fourth to the sixth centuries CE, of which fourteen can be reckoned to be certain. Most of these took place in Antioch, Syria and Palestine. He points out that if one adheres to the lachrymose view of Jewish history in late antiquity, this may be sufficient proof of extensive anti-Jewish violence, but one may also understand it in the light of a more complex view of Jewish-Christian relations, marked by fascination and rejection, tension and cohabitation. ${ }^{8}$ Depending on the narrative one adheres to, then, the attested instances of violence may be the tip of iceberg or isolated cases of escalation. We should therefore reflect as much on the narrative as on the evidence.

Second, almost all our evidence is of a literary nature and thus shaped by rhetoric and tropes. Pretending to report violence, our sources produce particular representations that conform to particular stereotypes and serve particular purposes. Hagiography, for example, is full of stereotypes about anti-pagan struggle, of which the destruction of idols and temples is one. These cannot be taken at face value. Indeed, contrary to the impression that his own writings might generate, there is only one certain case of temple destruction by the famously aggressive Egyptian abbot Shenoute (d. 465/ 466 $\mathrm{CE)} .{ }^{9}$ Rhetoric does not occur just in Christian texts. In his discourse For the Temples, Libanius consciously creates a picture of widespread destruction of temples by monks, fully knowing that the act was not allowed by law and that monks had a rather dubious reputation, also in Christian circles. As I have argued elsewhere, this text is not the eloquent testimony to pagan concerns about temple destruction for which it has been held, but a clever and subtle defence of elite interests by creating a picture of extensive illegal activity by monks. ${ }^{\text {IO }}$ If we do not contextualise each text carefully, we risk mistaking rhetoric for reality.

Increasingly aware of the limits of the traditional narrative and of the evidence, scholars have been exploring new avenues of research. One way is to embed episodes of violence in a broader social context. Acknowledging the

8 Wolfram Kinzig, 'Juden und Christen in der Antike. Trennungen, Transformationen, Kontinuitäten und Annäherungen', in R. Hvalvik and J. Kaufman (eds.), Among Jews, Gentiles and Christians in Antiquity and the Middle Ages. Studies in Honour of Professor Oskar Karsaune on his 65th Birthday (Trondheim: Tapir Academic Press, 20II), pp. I29-56.

9 Stephan Emmel, 'Shenoute of Atripe and the Christian Destruction of Temples in Egypt: Rhetoric and Reality’, in J. Hahn, S. Emmel and U. Gotter (eds.), From Temple to Church: Destruction and Renewal of Local Cultic Topography in Late Antiquity (Leiden: Brill, 2008), pp. I6I-20I.

Io Peter Van Nuffelen, 'Not the Last Pagan: Libanius between Elite Rhetoric and Religion', in L. Van Hoof (ed.), Libanius: A Critical Introduction (Cambridge: Cambridge University Press, 2014), pp. 293-314. 
fact that late antiquity was characterised by the coexistence of a variety of religious groups (both within Christianity and without), scholars seek to understand violence as one possible outcome of a wider social dynamic. Options abound: one can relate religious violence to pre-existing social tensions in cities and understand it as grafted onto different and older conflicts; one can study the formation of new identities in late antiquity and stress the tension between ordinary people with their multiple identities (civic, social, and religious) and the various religious groups that sought to promote membership in their group as the single overriding identity; or one can argue that late antiquity sees the continuation of the religious competition that marked the Roman Empire, but now with different groups dominating. All these approaches still start out from the assumption, seemingly borne out by the literary evidence, that religious identities became dominant in late antiquity. ${ }^{\text {II }}$ Yet, as a survey of conflict documented in Egyptian papyri from late antiquity has shown, religion is rarely a factor in the kinds of social conflicts that papyri document. ${ }^{\mathrm{I}}$ This suggests that religion had not yet become a primary identity for many and puts into perspective the numerous literary texts that suggest otherwise. The social landscape of late antiquity is not yet that of the medieval Middle East in which religious and social identity merge.

This brings us to the second approach, namely the contextualisation of religious violence in a wider history of violence. We should start out from the fact that various forms of violence were present in late antique society. Correction of subordinates (slaves, children, women) often included corporal punishment. Equally, children were regularly beaten in school. The threat with, or the effective application of punishment was part of a strategy of reform and re-education of offenders. The absence of a monopoly of violence on the part of the Roman state and the relatively thin presence of imperial representatives in the provinces also allowed powerful individuals to pursue their own interests: the sources are full of, undoubtedly exaggerated, criticism of rapacious tax collectors, unjust governors and looting soldiers. These

II See Eric Rebillard, Christians and Their Many Identities in Late Antiquity, North Africa, 200-450 CE (Ithaca, NY: Cornell University Press, 20I2); Wendy Mayer, 'Religious Conflict: Definitions, Problems and Theoretical Approaches', in W. Mayer and B. Neil (eds.), Religious Conflict from Early Christianity to the Rise of Islam (Berlin: De Gruyter, 2013), pp. I-I9.

I2 Bernard Palme, 'Political Identity versus Religious Distinction? The Case of Egypt in the Later Roman Empire', in W. Pohl, C. Gantner and R. Payne (eds.), Visions of Community in the Post-Roman World: The West, Byzantium and the Islamic World, 300-1100 (Farnham: Ashgate, 20I2), pp. 8I-98. 
were structural features of life in the later Roman Empire which were often complained about but rarely remedied. If these sorts of violence help to understand why contemporaries had a lower sensitivity for violence than we do, an important parallel for religious violence is the recurrent popular riots. One can cite famous episodes such as the killing of the charioteer in Thessalonica that was the cause for the execution of thousands of citizens on orders of Theodosius I ( $390 \mathrm{CE}$ ), the so-called riot of the statues in Antioch three years earlier, when its inhabitants protested against tax rises, and the long list of popular riots, often taking place in the hippodrome, in Constantinople. The Nika riot (532 CE), which nearly cost Justinian his throne, is the most famous example. If some of these could be religious in motivation, like the anti-pagan riots under Tiberius in $580 \mathrm{CE}$, they could be triggered equally well by famine or oppressive administrations. If scholarship traditionally considers the elite to be the real instigators of such riots, and in the case of religious violence usually blames bishops, the capacity of the people to be an independent actor should not be underestimated. There is plenty of evidence for popular riots that should be considered spontaneous group actions, like the revolt of the people of Constantinople when the popular bishop John Chrysostom was exiled in $403 \mathrm{CE}$. Such revolts could be very violent, resulting in lynch justice. Although it has not been exhaustively analysed, there is clear evidence that such popular riots drew on a repertoire of actions, which usually mimicked official public rituals. For example, the parading of heads on spikes, the dragging of a criminal through the streets and his cremation and burial outside the city, and the destruction of pagan or imperial statues can all be paralleled in the official repertoire, for example that of victory celebrations and the damnatio memoriae. Interestingly, as far as I can judge, no typically religious repertoire is attested to for later periods of European history: popular riots are not drawing on a repertoire linked to Christian ritual or theology. In this respect, popular ritualised behaviour Christianises at the equally slow pace as official public ritual, which only in the second half of the sixth century acquires an explicitly Christian face.

A third context is that of language. It is often assumed that aggressive language leads to violence. On that premise, a high rate of violence is proven by the often highly polemical, not to say insulting tone in which many late antique texts are couched. Such a relation is never straightforward, and definitely not so for antiquity. One should remember that vituperation is an integral part of ancient rhetoric, as any reader of speeches by Cicero and Demosthenes knows: genre and rhetorical rules may shape creation as well as 
reception of speeches. Societies at large but also specific subfields have particular metaphors that seemingly unconsciously dominate language: modern medicine, for example, often draws on the language of warfare to describe the battle against bacteria and viruses. Within Christianity, in turn, agonistic and military language abounds to describe spiritual progress. If it is obviously possible that such language reverts to its original meaning and becomes a trigger for violence, there is no reason to assume it always does and that military metaphor is, in itself, a cause of violence. Indeed, violent language can coexist with other discourses: as we shall see, late ancient Christianity also emphasised peacefulness when it came to actions. Finally, in some circumstances the use of violent language could be a way to deescalate a real threat of violence, as we shall see below when martyrdom is discussed. ${ }^{\mathrm{I} 3}$ Overall, there has been little socio-linguistic research done on violent language in late antiquity which could shed more light on these issues.

These various new avenues in scholarship provide a more profound contextualisation of religious violence and lead, in effect, to a dissolution of that very concept. Once freed of the idea of an all-encompassing religious violence that is born in late antiquity, we may be able to return to the evidence and reassess it with fresh eyes. Indeed, notwithstanding all the nuance we have just added, late antique sources clearly are preoccupied with violence. I do not wish to argue that late antique sources are more or less fascinated by it than classical sources. Rather, I suggest the late antique perception of violence has two specific characteristics. The first is the creation of a number of highly charged categories to describe reality, in particular 'martyrdom', 'persecution' and 'sacrifice'. I propose that Christian sources identify these as specifically religious, or more appropriately, sacred forms of violence, which are polemically ascribed to one's enemies (a proper Christian does not create martyrs, persecute, or sacrifice). Although 'martyrdom' and 'persecution' are regularly used as objective descriptors in a scholarly vocabulary, we should recognise that they are deeply relational, in that they describe what one's enemies do. Given the high degree of conflict in late antiquity, it should not surprise us that we see accusations of this type of violence proliferate. Second, these accusations play out against a background of the moral condemnation of violence. Violence was problematic and this can be noticed even in reports that seek to justify it. This does not mean that

I3 Josef Lössl, 'Sprachlich-ästhetische Darstellung und "Anwendung” von Gewalt in Texten frühchristlicher Apologeten - Das Beispiel der Rede Tatians an die Griechen',

Zeitschrift für Religionswissenschaft 20 (2012), 196-222. 
Christians did not engage in violence (man does contravene moral injunctions), but their justificatory strategies play out against a background of moral condemnation. I shall discuss these two elements in turn, each time beginning with a famous episode.

\section{Sacrifice, Martyrdom and Persecution}

In 39I C E the Serapion of Alexandria was spoiled of its contents and the statue of the pagan god Sarapis destroyed. Already in antiquity the end of the Serapeion was a famous event and it is described prominently by the pagan writer Eunapius and by four fifth-century church historians. ${ }^{\text {I4 }}$ Famous though it was, the precise course of events is impossible to reconstruct: the sources are contradictory and have filled up lacunae in their information with guesswork. According to the earliest Christian version, that of Rufinus (402/3 $\mathrm{CE})$, the course of events was as follows. During the refurbishment of a derelict basilica into a church, skulls were found in the basement. Taking this as proof of pagan crimes, Christians paraded these in the streets, which led to a violent response from the pagans. Street riots ensued, after which some pagans locked themselves up in the temple of Serapis, taking Christians hostage. After a deadlock of a few days, an imperial order finally declared that they could leave unharmed but that the idols should be destroyed. Published in $402 / 403$, Rufinus' account is highly stylised and dramatised and occupies nine out of thirty-four chapters in his last book. If such a literary stylisation renders Rufinus a problematic source for historical reconstruction, it underscores the purpose of this episode in his church history. In his account the episode displays paganism in its purest form. Biblical as well as GraecoRoman sources considered Egypt to be the land of idolatry, where animals were worshipped as deities. Rufinus thus seizes on the event to construct an archetypical image of paganism. This is underscored by the general anonymity of all actors in the episode, except for two pagans. The leader of the pagans locked up in the Serapeion is, significantly, called Olympus - the name of the mountain of the gods in classical mythology. Although a historical person, the fact that Rufinus mentions this name when leaving the others out underscores the link of Egyptian paganism with Hellenism. The second

I4 Eunap. VS 6.2I; Socrates, Hist. eccl. 5.I6; Sozom. 5.7; Theodoretus, Ecclesiastical history 5.22. The most detailed analysis of the episode is found in Johannes Hahn, Gewalt und religiöser Konflikt: Studien zu den Auseinandersetzungen zwischen Christen, Heiden und Juden im Osten des römischen Reiches (von Konstantin bis Theodosius II) (Berlin: Akademie Verlag, 2004), pp. I5-I20. 
named character is a fraudulent priest of Saturnus called Tyrannus - the tyrant. Tyrants, in antiquity, behave immorally and often violently, and the Egyptian pagans live up to that stereotype.

Indeed, when the pagans are locked up in the Serapeion with Christian prisoners, they commit the ancestral crimes of paganism: they organise a persecution and force their hostages to sacrifice. Christians who refuse are executed by crucifixion, and the dead are thrown into a cave. In that way, the pagans repeat the very acts that were revealed by the skulls in the basement of the basilica. Rufinus explicitly signals to his readers that these are crimes that reflect the very essence of paganism when citing from the official response to the event. The emperor declared that

satisfaction was not be sought for those whom the blood they had shed before the altars, had made martyrs and the glory of whose merits had overcome the pain of death, but that otherwise the cause of the evils and the roots of the discord which had taken up the defense of the idols should be eliminated, so that once these were done away with, the reason for the conflict might also disappear. ${ }^{15}$

Martyrdom and persecution, then, are caused by the very nature of paganism, that is, idolatry. Hence pagans exclude themselves from civilised society.

At the heart of Rufinus' story lies religious or even sacred violence: pagan altars demand blood sacrifice and they lead to persecution and martyrdom. Such sacred violence, exclusively ascribed to the pagans, is tacitly contrasted with two lesser forms of violence in which Christians participate. First, Rufinus notes that the conflict between pagans and Christians is usually limited to shouts and tension, but that it degenerates into a riot in this case. He clearly blames the pagans for this, yet also notes that Christians do not hold back. The episode thus starts off as an instance of ordinary violence, before degenerating into sacred violence. Second, Rufinus describes the dismemberment of the statue of Serapis in terms that strongly remind one of popular executions in late antique cities. ${ }^{16}$ Such acts of lynching were often condoned by the authorities and they expressed the symbolic exclusion of bad bishops, governors and functionaries from the city. One can also understand the destruction as mimicking an official condemnatio memoriae and so inflicting the same punishment on Serapis as on statues of usurpers and bad

I5 Rufinus, Ecclesiastical History II.22; Philip R. Amidon (trans.), The Church History of Rufinus of Aquileia, Books 10 and 11 (New York: Oxford University Press, 1997).

I6 Ibid., II.22-3. 
emperors. By describing the destruction of the statue in these terms, Rufinus tacitly underscores the legitimacy of the act.

The narrative of Rufinus is thus subtly structured by a juxtaposition of three forms of violence which receive different moral valuations. Such a structure allows him to underscore the deeply problematic nature of pagan sacred violence. This is usually missed in scholarly readings of the episode, as they start from the assumption that the whole episode is paradigmatic for late antique 'religious violence'. I concur that it is paradigmatic, but for different reasons. Rufinus illustrates how sacred violence is found with one's enemies and, in doing so, he combines in a single episode the three concepts that shape late antique Christian understandings of such violence: blood sacrifice, persecution and martyrdom.

In late antiquity blood sacrifice was in need of justification, and also among pagans. Yet the plausibility of Rufinus' narrative is based on the link Christians perceived between pagan blood sacrifice and human sacrifice (a link that is sometimes also found in pagan sources). This was, in turn, contrasted with the Christian rejection of blood sacrifice and a more general rejection of the shedding of blood. Indeed, a widespread moral discourse held that a proper Christian (and a fortiori a bishop) should not spill blood in times of peace (warfare was perceived to be a different, albeit not always unproblematic, matter). It explains well-attested interventions of bishops and monks to save criminals from execution, as well as the panegyrical accounts of late antique emperors who may condemn someone to death but never actually execute him. The rejection of gladiatorial and hunting games on the part of Christians was rooted in the same rejection of spilling human blood in peacetime. The pagan orator Libanius suggested that Christian governors should have to choose between being Christian or being a governor, for the latter position demanded that one was willing to wield the sword of execution. ${ }^{\text {I7 }}$ The link, then, which Rufinus makes between blood sacrifice and the tyrannical nature of paganism sums up how a particular religious practice became in his representation a symbol of general bloodthirstiness.

Second, the pagans in the Serapeion organised a persecution. Late antique Christians lived with a history of three centuries of persecution before Constantine. The Christianisation of the empire did not put end to this. Persecution continued outside the empire, in particular in the Persian

I7 Lib. 45.27. Peter Van Nuffelen, 'The Unstained Rule of Theodosius II: A Late Antique Panegyrical Topos and Moral Concern', in T. Van Houdt and G. Roskam (eds.), Imago Virtutis (Leuven: Peeters, 2004), pp. 229-56; Christopher P. Jones, Between Pagan and Christian (Cambridge, MA: Harvard University Press, 20I4), pp. 6I-77. 
Empire, but it was also perceived as a real possibility within the Christian Empire - notwithstanding our image of a triumphant Christianity. ${ }^{18}$ The persecution under the last pagan emperor Julian (36I-3 CE) only confirmed that anxiety. As a highly charged interpretation of reality, the label 'persecution' quickly came to be applied by particular Christian groups to legislation that targeted them or to bishops who sought to limit their gatherings. The category allowed the persecuted group to situate itself on the right side of the pagan-Christian divide and to accuse to other of doing what only pagans would do.

Finally, persecution results in martyrdom. In Rufinus' story, martyrdom appears in a very traditional, pre-Diocletianic form: it is death inflicted by pagans on Christians who refuse to deny their faith. In that sense, it is a form of death that is religious in nature, and results, conversely, in an elevated status within the Christian community. The presentation of Rufinus glosses over the numerous ambiguities and problems that martyrdom posed for Christianity. At once highly praiseworthy and yet not to be coveted, the deaths of martyrs and confessors could generate tensions in communities: it always needed to be established that someone was a true confessor or martyr and then ascertained how his status could be made compatible with existing hierarchies in communities. Such problems came to the fore in intraChristian conflicts: were the Donatists who died during Constantine's repression of the schism victims of persecution and hence martyrs, or were they recalcitrant heretics who had been punished by the state? Martyrdom is a status that depends on one's identification of the true church.

The discourse of martyrdom has been highlighted as an engine of late antique religious violence: martyrdom could be actively sought by attacking other religious groups or could serve as a justificatory ideology after the fact. ${ }^{19}$ The circumcelliones, depicted in Catholic sources as the stormtroopers of the North African Donatists, are, for example, alleged to have interrupted pagan celebrations to seek martyrdom - yet this is reported by Catholic sources who sought to discredit the Donatists. ${ }^{20}$ If the martyrdom discourse might arouse enthusiasm for violence, we underestimate its complexity if we only see it as a source of escalation. Indeed, as the Serapeion episode

I8 August. De civ. D. I8.52.

I9 This is most extremely stated in Philip Buc, Holy War, Martyrdom, and Terror: Christianity, Violence, and the West (Philadelphia: University of Pennsylvania Press, 2015), p. I53: 'In early Christian theology, martyrdom moved history forward'.

20 E.g. August. Ep. I85.3.I2. Cf. Michael Gaddis, There Is No Crime for Those Who Have Christ: Religious Violence in the Christian Roman Empire (Berkeley: University of California Press, 2005). 
illustrates, it could also serve to de-escalate violence. The edict of Theodosius does not impose any punishment on the pagans, who are clearly murderers. It orders only two things: the victims of the pagans are said to have obtained the status of martyr, and the destruction of idols is ordered. The first measure clearly aims at soothing the Christians while avoiding the infliction of more bloodshed (which would have required a military attack on the Serapeion). Such a pragmatic use of martyrdom language by political bodies can be observed elsewhere too. After Constantine decreed toleration of the Donatists in 32I CE, he stated that no punishment would be meted out to perpetrators of violence against Catholics, for their victims already enjoyed the status of martyr with God. Similarly, in the early fifth century, Marcellus of Apamea was killed when attacking pagan shrines. The provincial council refused to take action against his murderers on the grounds that Marcellus had received sufficient glory as a martyr. ${ }^{2 \mathrm{I}}$ Scholars have tended to read these instances as celebrations of martyrdom and post factum justifications of violence. In fact, there can be no doubt that in all these cases the authorities used the discourse to appease tensions by giving honour to the victims and amnesty to the criminals.

In late antiquity accusations of persecution and claims to martyrdom proliferate. I have argued that they connected contemporary events back to the origin narrative of Christianity: in martyrdom and persecution the primordial, pagan crimes against Christianity are re-enacted, crimes that are violent and bloody. Designating crimes that are far worse than ordinary murder, these categories are highly morally charged and therefore allow Christian groups to situate themselves on the right side of the Christianpagan divide. Within a context of enduring conflict within Christianity, accusations of persecution proliferate precisely because they allow narratives to be crafted that situate oneself on the right side of history, religion and morality.

\section{Condemnation of Violence}

If accusations of persecution and of the infliction of martyrdom refer back to originally pagan sacred violence, Christianity self-identified with peace and a rejection of violence. For example, shortly after the council of Ephesus (43I $\mathrm{CE}$ ), Eutherius of Tyana, a follower of Nestorius, opened his apology by complaining that while the church should stand for peace, his opponents had

2I Optatus, Against the Donatists, app. 9; Sozom. Hist. eccl. 7.I5. 
had recourse to violence to settle the dispute. ${ }^{22}$ One could dismiss this as a mere rhetorical opposition, for Nestorius was no stranger to heavy-handed tactics. Yet, such an interpretation misses the point: the strength of such an opening statement lies in the fact that Eutherius claims to be on the side of what the church should be and pretended to be. Violence, especially when perpetrated by churchmen, was therefore morally problematic. Such a discourse generates a high visibility for violence: the high-handed tactics by bishops in the many conflicts of the period are often criticised - usually by other bishops in order to discredit their opponents. Even the famous letter of Severus on the conversion of the Jews of Minorca, usually read as advertising violence against the Jews, also reflects this constellation.

Between 2 and ro February 4I8 CE all the Jews of the small Mediterranean island of Minorca converted to Christianity. We are informed about the event through the letter its bishop Severus composed a year later and sent to all bishops of the Mediterranean. Because the letter narrates how the synagogue burned down, it has been judged very severely as the propaganda of Christian hardliners showing how one should deal with Jews. ${ }^{23}$ In fact, the letter is better understood as apologetic in nature, seeking to disculpate Severus for a series of events that contravened fundamental Christian prescriptions, in particular the voluntary nature of conversion and general peacefulness, as well as imperial law. The text is probably best understood as an attempt to shore up support in the face of a formal complaint lodged with the authorities by a Jew or the Jewish community.

The letter has a clear structure. It opens with a geographical presentation, drawing on traditional stereotypes, whereby the western city of Jamona, dominated by Christians, is depicted favourably and eastern Magona, inhabitated by Jews, is described as unfertile and full of dangerous animals. A hostile equilibrium exists between both communities, which is interrupted when the relics of St Stephen arrive on the island. Suddenly, without further explanation, the Christians abandon their usual slack and start to seek to convert the Jews. To this purpose, they organise a debate between Severus and the leader of the Jews. The Jews try to avoid the debate and when the Christians travel to Jamona, they are attacked by the Jews. Both groups come to blows and the synagogue burns down. We are now halfway through the letter and the rest is taken up by describing how various debates lead to the conversion of all the Jews. Five hundred and forty souls are added to the

22 Eutherius of Tyana, Antilogia I.

23 Scott Bradbury, Severus of Minorca. Letter on the Conversion of the Jews (Oxford: Clarendon Press, 1996). 
church. The narrative is clearly influenced by hagiographical topoi and we should avoid reading it as an exact representation of the events.

Throughout the narrative, Severus seeks to show how he has lived up to the moral demands of the church. First of all, he has sought to convert the Jews by debate. As I have shown elsewhere, persuasion and debate were, for late antique Christians, the appropriate means to deal with religious conflict, and it was considered improper to coerce someone before having tried persuasion. Persuasion would lead one to freely and rationally accept his error and assent to the truth of orthodoxy. Indeed, Severus takes care to prove to the reader that his intention was only debate: he states that he has appended to the letter the document he prepared, containing answers to possible issues the Jews would raise. ${ }^{24}$ The appendix is lost, but its mention serves the rhetorical function of demonstrating the honesty of Severus' intentions. Indeed, the rest of the letter records no less than four discussions.

The clash at the synagogue is, however, the moot point in the whole narrative. The destruction of synagogues was illegal in this period and Severus clearly seeks to shift blame away from himself. First, the cause of the violence was the Jews: instead of accepting the debate, they gathered arms and Jewish women started throwing stones at the Christians. Second, the violence that ensued is rendered remarkably harmless. Severus admits that he was unable to restrain his flock and that both sides came to blows. Remarkably, however, nobody was hurt. Severus underlines this by claiming that no Jew has claimed to have been hurt and by narrating the single exception: a Christian slave was hit by a lost stone when stealing from the synagogue. This, then, allows Severus to underline that the Christians did not steal anything of value from the synagogue, although they did confiscate the Jewish holy books. Third, the crucial event, the burning of the synagogue, is dispensed with in a single sentence: 'A fire consumed all the ornaments of the building, except for the books and the silverware, together with the building itself. ${ }^{25}$ Nothing is said of how this came about and, in a striking act of linguistic deviation, the burning of the building is syntactically represented as accessory to the destruction of the decoration. For a text that supposedly glorifies anti-Jewish violence, the letter of Severus remains remarkably coy about the violence: indeed, it is all but made to disappear.

24 Severus, Letter 8.I-2; Peter Van Nuffelen, 'The End of Open Competition? Religious Disputations in Late Antiquity', in D. Engels and P. Van Nuffelen (eds.), Competition and Religion in Antiquity (Brussels: Société Latomus, 20I4), pp. I48-7I.

25 Severus, Letter I3.13. 
The letter of Severus is doubly apologetic. On the one hand, it seeks to demonstrate to his fellow Christians that nothing immoral had happened. Persuasion was the aim and the riot at the synagogue was a lamentable yet harmless exception, ultimately caused by the Jews themselves. On the other hand, it rejects all legal responsibility for the burning of the synagogue. Given the fact that the letter circulated a year after the actual event, it seems likely that he was seeking support when faced with a court case. At about the same time, an associate of Severus contacted Augustine, probably to seek support in relation to this event. ${ }^{26}$ Rather than a glorification of violence, then, the letter seeks to dispel the moral opprobrium and legal challenge with which Severus was faced in the wake of the events of February 418. By denying all wrong-doing, the text reaffirms the prevalent expectations of non-violent conversion, the primacy of debate, and the legal status quo.

\section{Conclusion}

This chapter has argued that the traditional identification of late antiquity with religious violence has obstructed more fine-grained analyses of social and religious change in this period, and, by setting religious violence apart, has hindered its contextualisation within late antique violence in general. Of course there were acts of violence perpetrated by religious individuals and groups, but it is questionable that these should set the tone in what ought to be a complex symphony of cohabitation and tension. If social theory is often called upon to offer a more complex image of late ancient religious interaction, including its violent aspect, I have focused on the categories with which late antique sources represent violence. Indeed, there can be no doubt that there is a high level of reporting of violence of all types in late ancient Christian sources. This is the product, I submit, of a morally charged distinction that the church made between itself and society. Identifying itself with peacefulness, society appeared as the wielder of the sword. The idea had limitations that jar somewhat with modern sensibilities: it excluded warfare and coercion in day-to-day social relations, including corporal punishment of subordinates. The shedding of blood in times of peace was seen as morally proscribed: capital punishment, for example, was called into question. Within these limitations, it generated moral expectations by which one was judged. In a context of intense conflict within the church, it should not surprise that accusations of the violation of such moral boundaries abounded and this is 
one reason why Christian reports of Christian conflict often highlight their violent nature. The distinction between church and society was, in turn, grafted on an opposition between Christian and pre-Christian, that is pagan, times. Exemplified in blood sacrifice and the persecutions it called forth, paganism was seen as a fundamentally violent religion. Paradigmatically described in Rufinus, paganism committed truly sacred violence, stemming from its very nature as a religion. An obviously highly charged view of paganism, it gave poignancy to later accusations of persecution that Christian groups would trade: acts of persecution were reenactments of originally pagan, criminal sacred violence. This moral grid, projected onto reality and related to specific understandings of religion and history, renders late antique violence visible to us. The justifications of Rufinus and Severus play on these premises. If this is a challenge to modern historians, it was also a challenge to contemporary actors. As we have seen in the case of Severus of Minorca, it also drew attention to how much late antique Christian society still fell short of the ideals it set forth.

\section{Bibliographic Essay}

The following works, more or less indebted to the traditional paradigm, provide good starting points for further reading. Frank R. Trombley, Hellenic Religion and Christianization: c. 370-529 (Leiden: Brill, 1993) explores all the evidence for the survival of paganism, tending to a maximalist interpretation of the evidence. Johannes Hahn, Gewalt und religiöser Konflikt: Studien zu den Auseinandersetzungen zwischen Christen, Heiden und Juden im Osten des römischen Reiches (von Konstantin bis Theodosius II (Berlin: Akademie Verlag, 2004) shows how seemingly religious violence is rooted in local social conflicts. The role of violence in identity formation and affirmation lies at the core of Michael Gaddis, There Is No Crime for Those Who Have Christ: Religious Violence in the Christian Roman Empire (Berkeley: University of California Press, 2005), which also discusses the mutual accusations of martyrdom and persecution. Not just concerned with late antiquity is Marie-Françoise Baslez, Les Persécutions dans l'Antiquité: victimes, héros, martyrs (Paris: Fayard, 2007). The entanglement of martyrdom and asceticism and its role in violence from Christian antiquity to early Islam is studied by Thomas Sizgorich, Violence and Belief in Late Antiquity: Militant Devotion in Christianity and Islam (Philadelphia: University of Pennsylvania Press, 2009), emphasising the role played by militant devotion in patrolling communal boundaries. Maijastina Kahlos, Forbearance and Compulsion: The Rhetoric of Religious Tolerance and Intolerance in Late Antiquity (London: Duckworth, 2009) inventorises the way late antique Christians discussed toleration. Brent Shaw, Sacred Violence: African Christians and Sectarian Hatred in the Age of Augustine (Cambridge: Cambridge University Press, 20II) is a study of the Donatist schism, setting it in its social and political context. Marie-Françoise Baslez (ed.), Chrétiens persécuteurs: destructions, 


\section{Religious Violence in Late Antiquity}

exclusions violences religieuses au IVe siècle (Paris: Albin Michel, 20I4) offers a sample of case studies and views on violence perpetrated by Christians.

Criticism of the paradigm can be found in Jan Bremmer's 'Religious Violence and Its Roots: A View from Antiquity', ASDIWAL. Revue genevoise d'anthropologie et d'histoire des religions 6 (20II), 7I-9, and 'Religious Violence between Greeks, Romans, Christians and Jews', in A. C. Geljon and R. Roukema (eds.), Violence in Ancient Christianity: Victims and Perpetrators (Leiden: Brill, 20I4), which highlights the biased reading of the ancient evidence and the deficient theoretical underpinning of identifying monotheism with violence. Wendy Mayer, 'Religious Conflict: Definitions, Problems and Theoretical Approaches', in W. Mayer and B. Neil (eds.), Religious Conflict from Early Christianity to the Rise of Islam (Berlin: De Gruyter, 2013), pp. I-I9 offers an overview of the positions and emphasises the importance of the neurosciences in providing a richer picture of the roles played by emotions and violence in human (and hence also religious) life. Peter Van Nuffelen, Penser la tolérance dans l'Antiquité tardive (Paris: Éditions du Cerf, 2016), upon which this chapter substantially relies, is an intellectual history of how persuasion and coercion were conceptualised in late antiquity that enters into a dialogue with modern conceptions. For a wide-ranging criticism of the perceived link between religion and violence see William T. Cavanaugh, The Myth of Religious Violence: Secular Ideology and the Roots of Modern Conflict (Oxford and New York: Oxford University Press, 2009). Harold A. Drake, Emily Albu and Jacob Latham (eds.), Violence in Late Antiquity: Perceptions and Practices (Aldershot: Ashgate, 2006) has a valuable section, with critical perspectives, on religious violence.

Drake, Albu and Latham's volume is also a good starting point for exploring other types of violence, for which see also Hélène Ménard, Maintenir l'ordre à Rome: IIe-IVe siècles ap. J.-C (Seyssel: Champ Vallon, 2004), which is focused on public order, and Rene Pfeilschifter, Der Kaiser und Konstantinopel. Kommunikation und Konfliktaustrag in einer spätantiken Metropole (Berlin: De Gruyter, 20I3), a study of popular riots in Constantinople with a focus on the emperor but with much material on riots in general. Jens-Uwe Krause, Gewalt und Kriminalität in der Spätantike (Munich: C. H. Beck, 20I4) is the first synthesis of criminal violence in late antiquity, emphasising the state as the prime cause. Julia Hillner, Prison, Punishment and Penance in Late Antiquity (Cambridge: Cambridge University Press, 2015) studies penance and imprisonment against a background of the Christian adoption of classical ideas about reform. For the role of ordinary people in doctrinal disputes and violence, the crucial work is Michel-Yves Perrin, Civitas confusionis. De la participation des fidèles aux controverses doctrinales dans l'antiquité tardive (IIIe s.-c. 430) (Paris: Éditions Nuvis, 20I6), but see also Júlio César Magalhâes de Oliveira, Potestas populi: participation populaire et action collective dans les villes de l'Afrique romaine tardive (vers $300-430$ apr. J.-C) (Turnhout: Brepols, 20I2). Troels M. Kristensen, Making and Breaking the Gods: Christian Responses to Pagan Sculpture in Late Antiquity (Aarhus: Aarhus University Press, 2013) studies from a mainly archaeological perspective the destruction of pagan statuary. 
